\title{
REDESCRIPTION OF THE STRIPED CATFISH MYSTUS TENGARA (HAMILTON, 1822) (SILURIFORMES: BAGRIDAE), INDIA
}

\author{
A. Darshan ${ }^{1}$, P.C. Mahanta ${ }^{2}$, A. Barat ${ }^{3} \&$ P. Kumar ${ }^{4}$ \\ ${ }_{1,2,3,4}$ Directorate of Coldwater Fisheries Research, Bhimtal, Nainital, Uttarakhand 263136, India \\ ${ }^{1}$ achom_darshan@yahoo.com (corresponding author), ${ }^{2}$ pcmahanta@rediffmail.com, ${ }^{3}$ abarat58@hotmail.com, \\ ${ }^{4}$ prem_nrc@rediffmail.com
}

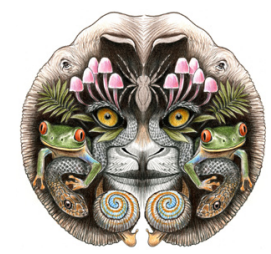

ISSN

Online 0974-7907

Print 0974-7893

OPEN ACCESS
Abstract: The Bagrid Catfish Mystus tengara was described from a pond located in India under the genus Pimelodus. The validity of the fish has been confused and has frequently been treated as a synonym of Mystus vittatus. In this study, the species is rediagnosed and redescribed on the basis of fresh material collected from the GangaBrahmaputra drainage. M. tengara is diagnosed from congeners in having a unique combination of the following characters: body with a distinct tympanic spot and four brown stripes which are separated by a pale narrow interspace; origin of adipose-fin not reaching the base of the last dorsal-fin ray, 31-42 gill rakers on first branchial arch, eye rounded with a diameter 19.0-23.8 \% HL and dorsal spine length 12.3-17.2 \% SL, maxillary barbel length 254.5-360.5 \% HL. A key for the identification of Mystus species from Ganga-Bramaputra drainage is also provided.

Keywords: Francis Hamilton, Ganga-Brahmaputra basin, Pimelodus tengara, redescription.

Hamilton (1822) described Pimelodus tengara (now Mystus) from a pond located in India. The identity of the fish is based solely on his description and drawings as he did not preserve any type specimens. The fish has often been treated as a synonym of Mystus vittatus (Bloch) (Venkateswarlu \& Menon 1979; Sharma \& Dutt 1983; Roberts 1992; Menon 1999).

Drashan et al. (2010) redescribed and revalidated Mystus carcio (Hamilton) which had previously been considered as a synonym of either $M$. tengara or $M$. vittatus. They also treated the latter two species as valid. However, a detailed description of $M$. tengara is lacking.

In the present study, several fish specimens consistent with Hamilton's (1822) description of Mystus tengara were examined. Here we redescribe $M$. tengara and distinguish it from its closest congener, $M$. vittatus and other striped Mystus of the Ganga-Brahmaputra drainage, viz., M. dibrugarensis (Chaudhuri), M. cavasius (Hamilton), M. carcio (Hamilton), M. gulio (Hamilton) and $M$. bleekeri (Day).

\section{Materials and Methods}

Measurements were made with a dial caliper to the nearest $0.1 \mathrm{~mm}$. Subunits of the head are presented as proportions of head length ( $\mathrm{HL})$. Head length and measurements of body parts are given as proportions of standard length (SL). Methods for counts and measurements follow Ng \& Dodson (1999). Numbers in parentheses following a count are the number of specimens with that count. Dorsal fin height is measured from the base of spinelet to the highest point of the dorsal fin. Twenty specimens were dissected and cleared for osteological studies. Clearing and staining of specimens follow Hollister (1934) and osteological nomenclature follows Mo (1991) and Darshan et al. (2010). Gill rakers were counted on the first left branchial

DOI: http://dx.doi.org/10.11609/JoTT.o2813.842 | ZooBank: urn:Isid:zoobank.org:pub:E3B36E3A-296A-4113-8EE7-6332EC07655F

Editor: W. Vishwanath, Manipur University, Imphal, India.

Date of publication: 26 January 2013 (online \& print)

Manuscript details: Ms \# o2813 | Received 24 May 2011| Final received 19 November 2012 | Finally accepted 29 December 2012

Citation: A. Darshan, P.C. Mahanta, A. Barat \& P. Kumar (2013). Redescription of the Striped Catfish Mystus tengara (Hamilton, 1822) (Siluriformes: Bagridae), India. Journal of Threatened Taxa 5(1): 3536-3541; doi:10.11609/JoTT.o2813.842

Copyright: @ Darshan et al. 2013. Creative Commons Attribution 3.0 Unported License. JoTT allows unrestricted use of this article in any medium, reproduction and distribution by providing adequate credit to the authors and the source of publication.

Funding: Department of Biotechnology, Government of India (DBT- RA program commencing from July 2009).

Competing Interest: None.

Acknowledgements: The authors are thankful to Prof. W. Vishwanath for giving access to D.D. Mukerji's captions from Hamilton's manuscript and valuable comments. The first author is grateful to Department of Biotechnology, Government of India for awarding fellowship under DBT- Postdoctoral program in Biotechnology and Life Sciences. 
arch in 17 specimens. Methods for counting gill rakers and vertebrae follow Roberts (1992) and Roberts (1994) respectively. The examined materials are deposited in the Manipur University Museum of Fishes (MUMF) and Directorate of Coldwater Fisheries Research (DCFR) fish Museum.

\section{Mystus tengara (Hamilton, 1822)}

(Fig. 1; Images 1 \& 2b)

Pimelodus tengara Hamilton, 1822: 183, PI.3, fig. 61 (type locality: Ponds of India).

Bagrus tengara Valenciennes, in Cuvier \& Valenciennes, 1840: 414.

Macrones tengara Day, 1877: 447, PI. Cl, fig. 5 (in parts, description).

Mystus tengara Misra, 1976: 104; Jayaram \& Singh, 1977: 263 (name only); Talwar \& Jhingran, 1991: 571, fig. 189 (in part); Jayaram \& Sanyal, 2003: 107, fig. 25; Jayaram, 2006: 54, fig. 21 (in part); Vishwanath et al., 2007: 135, fig. 174 (description and figure); Shrestha, 2008: 151, pl. 39, fig. 131 (description and figure); Darshan et al., 2010: 51-53, fig. 2, 4d \& b (description and fig.); Darshan et al. 2011: 2182 (comparative description).

Mystus vittatus Shrestha, 2008: 151, pl. 40, fig. 132 (description and figure); Shaw \& Shebbeare, 1937: 94 (in parts); Roberts, 1992: 81, fig.2.

Material examined: 1 ex., v.2009, 74.6mm SL, Brahmaputra River at Goalpara, Assam, India 26011'46" N \& 90³8'04"E, coll. A. Darshan (MUMF 9535); 20 ex., 24.v.2007, 67.9-75.7 mm SL, Kolkata, West Bengal, India, coll. A. Darshan (MUMF 9520/1 - MUMF 9520/20); 15 ex., 30.xii.2008, 52.1-77.5 mm SL, Brahmaputra River at Guwahati, India (MUMF 9523/1 - MUMF 9523/15); 8 ex., 12.x.2009, 67-86 mm SL, wetlands of Comilla District, Bangladesh, purchased in Agartala fish market, Tripura, India, coll. W. Vishwanath (Unregistered); 2 ex., 16.vii.2008, 75.8-85.6 mm SL; Ganga River at Patna,

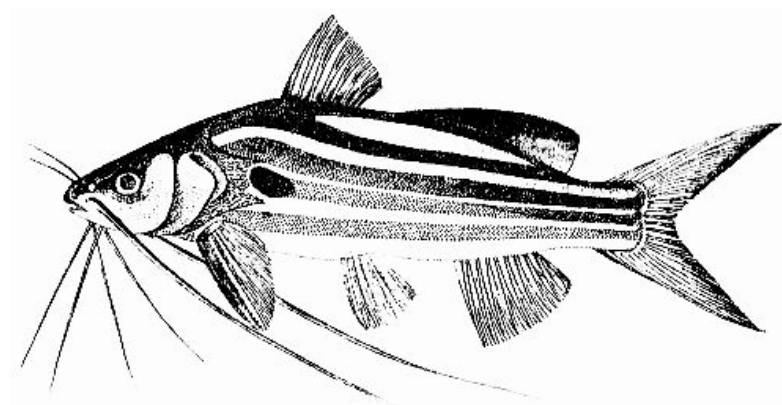

Figure 1. Mystus tengara: illustration from Hamilton, 1822 (PI. 3, Fig. 61).

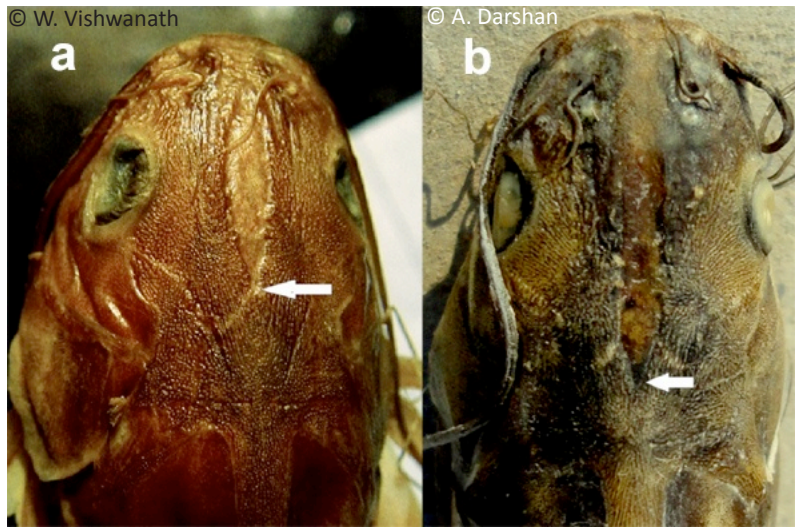

Image 2. Dorsal view of head showing the posterior extremity of posterior fontanel.

a - Mystus vittatus (Bloch), MUMF 9527, 72.7mm SL;

b - Mystus tengara (Hamilton), MUMF 9523, 73.5mm SL

India, coll. R.K. Sinha (MUMF 9534/1 - MUMF 9534/2); 23 ex., 14-15.v.2010, 58.5-88.4 mm SL, Ganga River at Gai-Ghat, Patna, India, coll. A. Darshan \& Rajesh Sinha (MUMF 9539/1 - MUMF 9539/23); 15 ex., 17-18. iii.2011, 76-95 mm SL, Sarda Sagar reservoir situated at the border of Uttarakhand and Uttar Pradesh states, India, $28^{\circ} 40^{\prime} \mathrm{N} \& 80^{\circ} 2^{\prime} \mathrm{E}$, coll. A. Darshan and party (DCFR Unregistered).

Diagnosis: Mystus tengara differs from its congeners

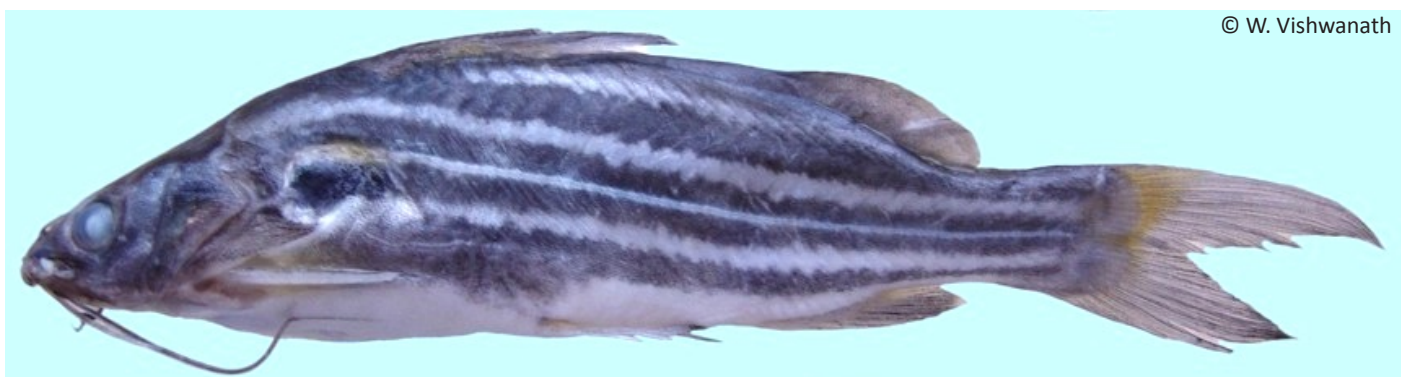

Image 1. Mystus tengara (Hamilton), MUMF 9535, 74.6mm SL, lateral view 
by a unique combination of the following characters: body with a distinct tympanic spot and four brown stripes which are separated by pale narrow interspaces; origin of adipose-fin not reaching the base of last dorsal- fin ray, 31-42 gill rakers on first branchial arch, eye rounded with a diameter 19.0-23.8\% HL and dorsal spine length 12.3-17.2 \% SL, maxillary barbel length 254.5-360.5\% $\mathrm{HL}$.

Description: Morphometric data are given in Table 1. Dorsal profile rising evenly from tip of snout to origin of dorsal fin then sloping gradually ventrally from there to the end of caudal peduncle. Ventral profile roughly straight up to the end of anal fin base, then sloping gently dorsally to the end of the caudal peduncle.

Head depressed. Skin covering dorsal surface of head thin. Anterior cranial fontanel extends from the level of posterior nasal opening to posterior orbital margins, separated from posterior fontanel by a narrow epiphyseal bar. Posterior fontanel extends to base of occipital process in juvenile and upto anterior one-third of supraoccipital bone in adult. Supraoccipital process long, wide at base about one-fifth of its length, reaching basal bone of dorsal fin, tapering distally. Eye rounded, located entirely in dorsal half of head.

Mouth sub-terminal. Oral teeth small and villiform, arranged in irregular rows. Premaxillary tooth band slightly curved backward, of equal width throughout. Tooth band on vomer continuous across midline and crescentic, band width about one-third of premaxillary with equal width throughout, extending to the level of lateral end of premaxillary tooth band. Dentary tooth band separated in the middle by thick skin, slightly broader than premaxillary tooth band at symphysis, tapering posterolaterally. Gill openings wide and free from isthmus. First branchial arch with $8+23=31(4)$ or $9+24=33(2)$ or $9+25=34(3)$ or $8+27=35(2)$ or $8+31=$ $39(3)$ or $9+32=41(2)$ or $10+32=42$ (1) gill rakers.

Barbels in four pairs, maxillary pair reaching at least posterior end of anal fin base in adult and frequently reaching distal tip of caudal fin or beyond in juvenile specimens, nasal reaching base of occipital process, outer mandibular reaching distal tip of pectoral fin and inner mandibular barbel extend upto base of pectoral fin. Skin smooth. Lateral line complete and midlateral in position.

Dorsal-fin with spinelet, spine and seven branched rays. The spine is serrated anteriorly near the distal tip with 2-4 serrations and posteriorly with 8-10. Adipose fin long, origin not reaching base of last dorsal fin ray and deeply incised at posterior end. Pectoral fin with a backwardly curved stout spine and 7-8 branched
Table 1. Morphometric data of Mystus tengara $(n=36)$.

\begin{tabular}{|c|c|c|}
\hline In \% of SL & Range & Mean $\pm S D$ \\
\hline Predorsal length & $37.6-40.8$ & $40.2 \pm 1.5$ \\
\hline Preanal length & $71.2-72.6$ & $71.9 \pm 0.7$ \\
\hline Prepelvic length & $49.1-55.4$ & $52.2 \pm 1.9$ \\
\hline Prepectoral length & $22.3-25.4$ & $23.6 \pm 0.8$ \\
\hline Height of dorsal fin & $20.9-26.5$ & $23.5 \pm 1.7$ \\
\hline Length of dorsal-fin base & $12.2-15.2$ & $13.9 \pm 1.2$ \\
\hline Dorsal spine length & $12.3-17.2$ & $14.1 \pm 1.8$ \\
\hline Anal-fin length & $16.9-20.4$ & $18.2 \pm 1.0$ \\
\hline Pelvic-fin length & $13.9-17.8$ & $15.7 \pm 1.0$ \\
\hline Pectoral-fin length & $17.9-23.2$ & $20.1 \pm 1.4$ \\
\hline Pectoral-spine length & $15.0-20.4$ & $17.6 \pm 1.6$ \\
\hline Caudal-fin length & $26.6-30.7$ & $28.3 \pm 1.5$ \\
\hline Length of adipose-fin base & $24.0-31.7$ & $28.8 \pm 2.2$ \\
\hline Adipose maximum height & $4.0-5.7$ & $5.3 \pm 0.5$ \\
\hline Post-adipose distance & $13.6-17.1$ & $15.4 \pm 1.0$ \\
\hline Caudal peduncle length & $16.3-19.9$ & $17.9 \pm 1.2$ \\
\hline Caudal peduncle depth & $9.8-11.6$ & $10.8 \pm 0.6$ \\
\hline Body depth at anus & $20.7-24.3$ & $21.6 \pm 1.4$ \\
\hline Head length & $26.9-28.9$ & $28.0 \pm 0.7$ \\
\hline Head width & $16.5-19.6$ & $17.9 \pm 0.9$ \\
\hline Head depth & $16.2-19.8$ & $17.9 \pm 2.4$ \\
\hline \multicolumn{3}{|l|}{ In \% of $\mathrm{HL}$} \\
\hline Snout length & $32.7-36.5$ & $34.8 \pm 1.6$ \\
\hline Eye diameter & $19.0-23.8$ & $21.1 \pm 1.4$ \\
\hline Interorbital distance & $32.3-37.5$ & $35.5 \pm 1.7$ \\
\hline Nasal barbel length & $55.3-84.8$ & $66.1 \pm 7.9$ \\
\hline Maxillary barbel length & $254.5-360.5$ & $297.6 \pm 37.8$ \\
\hline Inner mandibular barbel length & $62.3-94.9$ & $79.1 \pm 11.2$ \\
\hline Outer mandibular barbel length & $110.4-151.3$ & $135.3 \pm 10.7$ \\
\hline
\end{tabular}

rays. Spine with 11-16 large posterior serrations and anteriorly rough. Posterior fin margin almost straight. Pelvic fin short with i, 5 rays. Anal fin with ii-iii, $7-10$ rays. Caudal fin deeply forked with $\mathrm{i}, 7,7, \mathrm{i}$ or $\mathrm{i}, 7,8, \mathrm{i}$ or $\mathrm{i}, 8,8, \mathrm{i}$ rays, upper lobe longer.

Osteological character: Branchiostegal with 9(20) rays. Ribs with $8-9$, attached from $6^{\text {th }}$ to $13^{\text {th }}$ or $14^{\text {th }}$ vertebra. Vertebrae with $18+16=34(1)$ or $19+15=34(1)$ or $19+16=35(3)$ or $20+15=35(2)$ or $19+17=36(6)$ or $20+16=36(6)$ or $20+17=37(1)$. Closed haemal canal appears from $11^{\text {th }}(20)$ vertebra onwards. Caudal fin with five hypural plates (20), three on the upper and two on the lower lobe. Parhypural free from first hypural plate. Hypurapophysis and secondary hypurapophysis fused. Procurrent rays respectively with 12 and 13 on upper 
and lower lobe of caudal fin. Epural: single, laterally flattened and curved backward.

Colouration: Specimens preserved in $10 \%$ formalin have a body with a distinct oval dark brown tympanic spot and four brown stripes (a mid-dorsal and three lateral stripes), all the stripes are separated by pale longitudinal lines of equal wide. The pale longitudinal lines separating the mid-dorsal and lateral stripes originate from below the middle of the base dorsal fin and extend up to the posterior portion of adipose fin base. Lateral lines appear as thin pale lines in the middle of the midlateral stripe.

Distribution: Ganga and Brahmaputra drainage in India, Bangladesh and Nepal. The species is also recorded from Narmada and Mahanadi basins in northern India, Indus River drainage of Pakistan (Talwar \& Jhingran 1991; Mirza 2003) and Afghanistan (Coad 1981).

\section{Discussion}

Roberts (1998) reported that Francis Hamilton made all his drawings from fresh specimens and discarded them after completing the drawing and did not preserve any type specimen. He also reported that the description of the fishes were written later (sometimes much later) from the drawings. Robert's (1998) assumption might be partly correct. But Francis Hamilton must have certainly noted some important points about the fishes, without which he would not have been able to write detailed descriptions of all the 271 species in his book on Gangetic fishes. Mukherji (1931), on the basis of the manuscript of Hamilton's Gangetic fishes, reported that Mystus tengara was collected from Brahmaputra River at Goalpara, on 29 July 1808 . Goalpara was the place where Francis Hamilton stayed as the rainy season station in 1808 during his Bengal survey. The name 'tengara' is in fact a Bengali or Assamese local name of Pimelodus tengara (now Mystus). Hamilton (1822) usually used local names in naming a fish.

Hamilton (1822) mentioned that 'tengara' was very common in the ponds of India. Subsequent workers felt the type locality mentioned in the original description may not be correct and modified it without giving any reason (examples: lower Bengal: Sharma \& Dutt 1983; India: Roberts 1992; northern parts of Bengal: Talwar \& Jhingran 1991; Jayaram 2006, Jayaram \& Sanyal 2003). It can be assumed that the type locality of Mystus tengara is in the Ganga-Brahmaputra basin on the basis of Mukerji's (1931) report of its collection and also the fact that Hamilton's (1822) work on Gangetic fishes was confined to this basin. Thus, striped catfishes of the genus Mystus from the Ganga-Brahmaputra basin have been made in order to redescribe $M$. tengara and to clarify its type locality.

Hamilton (1822) shows two figures (plate 3, fig. 61) of Mystus tengara along with the description of the fish. One of his figures shows the lateral view, showing the striped pattern of the fish (see fig. 1) and another the dorsal view showing the extent of the cranial fontanel invading the supraoccipital region. A cleared and stained mature specimen of $M$. tengara clearly shows that half of the posterior fontanel is located at the posterior portion of frontal and the remaining portion at the supraoccipital bone. In the case of $M$. vittatus, posterior fontanel tapers posteriorly to a point at the anterior border of the supraoccipital bone, not invading the supraoccipital region. The same structure can also be observed in the formalin preserved specimens after drying for some time (Image 2). Moreover, Mystus tengara differs from M. vittatus (Image 3 ) in having a longer maxillary barbel length (254.5-360.5 \% HL vs. 214.3-244.9) and dorsal spine length (12.3-17.2 \% SL vs. 10.7-12.2); body colour pattern consisting of a dark brown oval tympanic spot with distinct margin (vs. diffuse tympanic spot); four brown stripes (for details see description) separated

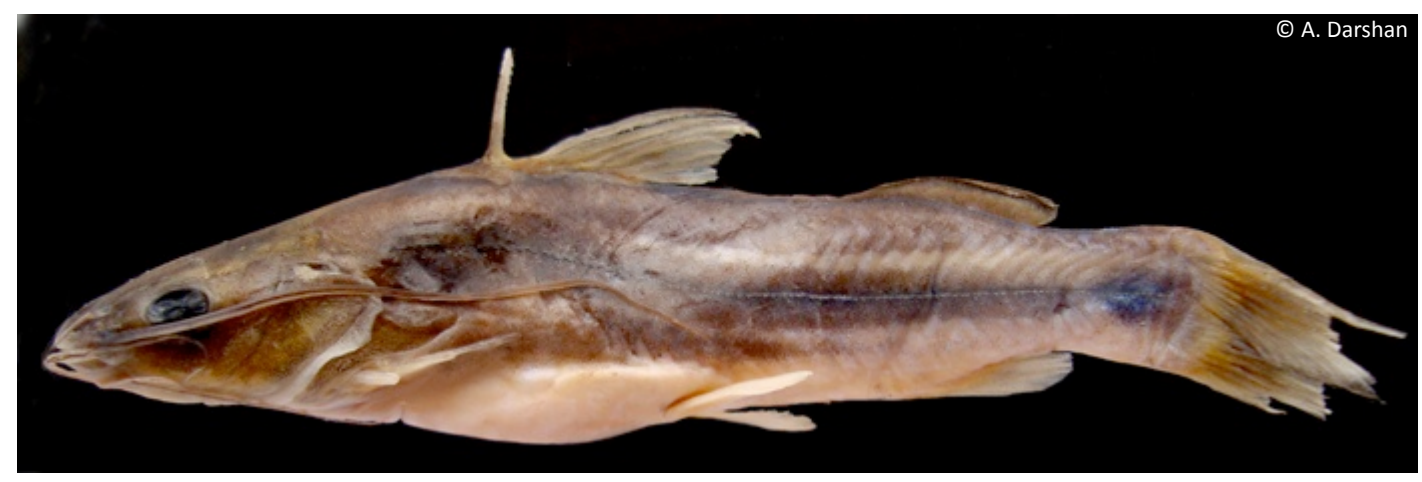

Image 3. Mystus vittatus (Bloch, 1794), EBS/ZSI/F-6140, 94.3mm SL, lateral view. 
by the three pale interspace lines (vs. three brown stripes separated by two pale interspace lines of equal width, one above and another below the mid-lateral stripe). Moreover, M. vittatus has a diffused dark spot at the base of caudal fin, sometimes indistinct in some specimens (vs. no such spot in M. tengara). Day (1877) also observed this black spot in $M$. vittatus collected from Madras (southern India), though Bloch (1794) did not mention it.

Our extensive surveys of the Ganga and Brahmaputra River drainage have not encountered any species of Mystus with a short posterior fontanel (not invading the supraoccipital region) as in Mystus vittatus. Several records of $M$. vittatus from northeastern India and Gangetic basin were found to be misidentifications of either M. tengara or M. carcio (Darshan et al. 2010; above list of synonymy). For easy identification the species has also been incorporated in the given artificial key.

Mystus tengara differs from $M$. bleekeri in having a shorter adipose-fin base (24.0-31.7\% SL vs. 42.0-47.2); adipose-fin origin not in contact with the base of last dorsal fin ray (vs. in contact), more gill rakers on the first branchial arch (31-42 vs. 11-15) and fewer vertebrae (34-37 vs. 38-40). It differs from $M$. dibrugarensis in having more number of gill rakers (31-42 vs. 28) on the first arch and also in the absence of a thin black midlateral line and the black spot at the base of the caudal fin (vs. presence). M. tengara differs from $M$. carcio in having a smaller eye (diameter: 19.0-23.8\% HL vs. 39.342.3), wider interobital (32.3-37.5 \% HL vs. 25.6-30.7), adipose-fin base (24.0-31.7\% SL vs. 8.5-11.9), maxillary barbel (254.5-360.5 \% HL vs. 151.9-195.8); shallower head (16.2-19.7 \% SL vs. 21.9-25.9) and body depth at anus (20.7-24.3 \% SL vs. 24.4-28.2); shorter postadipose distance (13.6-17.1\% SL vs. 17.9-20.5), pectoral spine length (15.0-20.4\% SL vs. 22.1-31.1); absence of coracoid shield (vs. presence) and continuous vomerine tooth band (vs. separated).

\section{Comparative material and sources:}

Mystus vittatus: EBS/ZSI/F-6140, 4 ex., 73.9-94.3 mm SL, India: Tamil Nadu, Cauvery River near Kumbakonam. MUMF 9527-9528, 2 ex., 72.7-76.8 mm SL, India: Tamil Nadu Tranquebar; ZSI Unregistered, 10 ex., 69.1-80.1 $\mathrm{mm}$ SL, southern India: freshwater pond at Tranquebar, coll. by Prof. R. Natarajan, 06.iv.1985.

Mystus bleekeri: ZSI 1076, (lectotype), 101.5mm SL, India: Yamuna River, date unknown. MUMF 9521, 10 ex., 85.6-108.3 mm SL, India: Ganga River at Patna, 16.vii.2008. MUMF 9522, 10 ex. 74.2-98.8 mm SL, India: Brahmaputra River at Guwahati, 30.xii.2008.

Mystus gulio: Data from Jayaram \& Sanyal (2003).

Mystus carcio: ZSI FF4081 (1), 47.9mm SL, India: Assam: Brahmaputra River at Guwahati. ZSI FF4080 (1), 42.9mm SL, same data a above. MUMF 9518/1 (1), 39.0mm SL, India: Assam: Brahmaputra River at Guwahati. MUMF 9518/3-9518/10 (8), 30.2-47.9 mm SL; same data as above. MUMF 9519/1-9519/17 (17), 39.0-47.0 mm SL, same data as above. MUMF 9531 (1), 36 mm SL; India: Assam: Ujan Bazar, Guwahati.

Mystus dibrugarensis: Unregistered (5), 68.5-78.1 mm SL, India: Assam: Dibru River at Tinsukia.

\section{REFERENCES}

Bloch, M.E. (1794). Naturgeschichte der ausländischen Fische.

Artificial key to the identification of Mystus species distributed in Ganga Brahmaputra drainage

\begin{tabular}{|c|c|}
\hline & 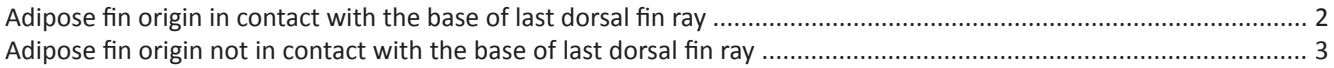 \\
\hline & istinct humeral mark and nuchal spot present ...... \\
\hline & Body with distinct lateral stripe but lacking both the humeral mark and nuchal spot. \\
\hline & Supra occipital process not in contact with the basal bone dorsal fin . \\
\hline & Supraoccipital process in contact with the basal bone of dorsal fin ... \\
\hline & A thin dark grey midlateral stripe running along the lateral line ending on a black spot located at the base of caudal \\
\hline & Lacking both the dark grey thin mid-lateral stripe running on the lateral line and the black spot at the base of caudal \\
\hline & $\begin{array}{l}\text { Adipose fin base length equal to or shorter than that of the dorsal fin base length, coracoid shield present, vomerine } \\
\text { tooth band separated in the middle }\end{array}$ \\
\hline & $\begin{array}{l}\text { Adipose fin base length } 2 \text { to } 2.5 \text { times longer than that of the dorsal fin base, coracoid shield absent and vomerien } \\
\text { tooth band continuous }\end{array}$ \\
\hline & $\begin{array}{l}\text { Posterior fontanel long, extended into the supra occipital region reaching upto the middle of supra occipital bone (in } \\
\text { mature specimens) }\end{array}$ \\
\hline & el short, ending at the anterior tip the supraoccipital bone (in mature specimens) \\
\hline
\end{tabular}


Schlesinger, Berlin, 8: 1-174, pls. 361-396.

Coad, B.W. (1981). Fishes of Afghanistan, an annoted checklist. National Museum of Canada Publications in Zoology 14: i-v + 1-26.

Cuvier, G. \& A. Valenciennes (1840). Histoire Naturelle des Poissons. Tome Quartozième. Pitois-Levrault, Paris, 464pp+pls. 389-420.

Darshan, A., N. Anganthoibi \& W. Vishwanath (2010). Redescription of the striped catfish Mystus carcio (Hamilton) (Siluriformes: Bagridae). Zootaxa 2475: 48-54.

Darshan, A., W. Vishwanath, P.C. Mahanta \& A. Barat (2011). Mystus ngasep, a new catfish species (Teleostei: Bagridae) from the headwaters of Chindwin drainage in Manipur, India. Journal of Threatened Taxa 3(11): 2177-2183.

Day, F. (1875-78). The Fishes of India; Being a Natural History of the Fishes Known to Inhabit the Seas and Fresh Waters of India, Burma, and Ceylon. Bernard Quaritch, London, 778 pp, pls. 195.

Hamilton, F. (1822). An Account of The Fishes Found in The River Ganges and Its Branches. Archibald Constable, Edinburgh and Hurst, Robinson, London, 405pp.

Hollister, G. (1934). Clearing and dying fishes for bone study. Zoologica 12: 89-101.

Jayaram, K.C. (2006). Catfishes of India. Narendra Publishing House, Delhi, 383pp.

Jayaram, K.C. \& A. Sanyal (2003). A taxonomic revision of the fishes of the genus Mystus Scopoli (Family: Bagridae). Records of the Zoological Survey of India Occasional Paper 207: 1-136.

Jayaram, K.C. \& K.P. Singh (1977). On a collection of fish from north Bengal. Records of Zoological Survey of India 72: 243-275.

Menon, A.G.K. (1999). Checklist of freshwater fishes of India. Records of Zoological Survey of India, Miscellaneous Publication, Occasional Paper No. 179: 1-366.

Mirza, M.R. (2003). Checklist of freshwater fishes of Pakistan. Suppl. Ser. 3: $1-30$

Misra, K.S. (1976). The Fauna of India and Adjacent Countries. Pisces. Vol. III. Teleostomi: Cypriniformes; Siluri. Zoological Survey of India Calcutta, 367pp.

Mo, T.P. (1991). Anatomy, Relationships and Systematics of The
Bagridae (Teleostei: Siluroidei) With A Hypothesis of Siluroid Phylogeny. Theses Zoologicae 17. Koeltz, Koenigstein, 216pp.

Mukerji, D.D. (1931). Captions Copied from Hamilton-Buchanan's MS. of Gangetic Fishes. Unpublished manuscript, 44pp.

Ng, H.H. \& J.J. Dodson (1999). Morphological and genetic descriptions of a new species of catfish, Hemibagrus chrysops, from Sarawak, east Malaysia, with an assessment of phylogenetic relationships (Teleostei: Bagridae). The Raffles Bulletin of Zoology 47: 45-57.

Roberts, T.R. (1992). Revision of the striped catfishes of Thailand misidentified as Mystus vittatus, with descriptions of two new species (Pisces: Bagridae). Ichthyological Exploration of Freshwaters 3: 77-88.

Roberts, T.R. (1994). Systematic revision of Asian bagrid catfishes of the genus Mystus sensu stricto, with a new species from Thailand and Cambodia. Ichthyological Exploration of Freshwaters 5: $241-$ 256.

Roberts, T.R. (1998). Francis Hamilton and the freshwater stingrays described in his Gangetic fishes (1822). Archives of Natural History 25(2): 267-280.

Sharma, S.V. \& S. Dutt (1983). Taxonomic studies on four species of the genus Mystus Scopoli, 1777 (Siluriformes: Bagridae). Records of Zoological Survey of India 81: 331-344.

Shaw, G.E. \& E.O. Shebbeare (1937). The fishes of northern Bengal. Journal of Royal Asiatic Society of Bengal, Science 3: 1-137, Pls. 6.

Shrestha T.K. (2008). Ichthyology of Nepal. Himalayan Ecosphere, Nepal, 390pp+72pl.

Talwar, P.K. \& A.G. Jhingran (1991). Inland Fishes of India and Adjacent Countries (Vol. 1 \& 2). Oxford \& IBH Publishing Co. Pvt Ltd., New Delhi, 1062pp.

Venkateswarlu, T. \& A.G.K. Menon (1979). A list of fishes of the river Ganges and its branches. Acta Ichthyologica Et Piscatoria Vol. 1X Fasc. 1

Vishwanath, W., W.S. Lakra \& U.K. Sarkar (2007). Fishes of North East India. National Bureau of Fish Genetic Resources, Lucknow, UP., India, 264pp. 